\title{
Differential Effects of 1-Methylcyclopropene on Citrus Leaf and Mature Fruit Abscission
}

\author{
Luis Pozo, Rongcai Yuan, Igor Kostenyuk, Fernando Alférez, Guang Yan Zhong, and \\ Jacqueline K. Burns ${ }^{1}$ \\ Horticultural Sciences Department, University of Florida, Institute of Food and Agricultural Sciences, \\ Citrus Research and Education Center, 700 Experiment Station Road, Lake Alfred, FL 33850
}

\begin{abstract}
AdDitional Index words. 5-chloro-3-methyl-4-nitro-1H-pyrazole, Citrus sinensis, coronatine, ethephon, fruit detachment force, methyl jasmonate

Aвstract. 1-MCP is a gaseous ethylene binding inhibitor that controls or delays ethylene-related postharvest problems in a range of horticultural commodities. Our previous work demonstrated that exposure of calamondin to 1-MCP 16 hours before canopy sprays of ethephon greatly reduced unwanted leaf drop while only partially inhibiting the ability of ethephon to cause fruit loosening. The objective of this work was to determine whether formulated 1-MCP (SmartFresh) could be used in the field to stop defoliation caused by abscission agent applications without significantly altering abscission agent-induced fruit loosening. Spray solutions containing $400 \mathrm{mg} \cdot \mathrm{L}^{-1}$ ethephon with $0,1,2.5$, and 5 mм 1-MCP were applied to canopies of 'Hamlin' and 'Valencia' (Citrus sinensis). Timing of 1-MCP applications was a) 24 hours before, b) in combination with, or c) 24 hours after ethephon. Ethephon at $400 \mathrm{mg} \cdot \mathrm{L}^{-1}$ significantly reduced fruit detachment force (FDF) but caused $>70 \%$ leaf drop within 15 days after application in both cultivars. Applications of 1-MCP reduced ethephon-associated leaf abscission but had little effect on the ability of ethephon to reduce FDF. Timing of 1-MCP applications did not affect the ability of ethephon to cause fruit loosening; however, the best consistent treatment for control of leaf drop was achieved with the combined application of 5 mM 1-MCP and 400 $\mathrm{mg} \cdot \mathrm{L}^{-1}$ ethephon. 1-MCP was used in combination with the abscission agents coronatine, methyl jasmonate (MeJa) and 5-chloro-3-methyl-4-nitro-1H-pyrazole (CMNP) to determine its effect on leaf drop and fruit loosening. Leaf drop in trees treated with ethephon, coronatine, and MeJa was reduced by addition of 1-MCP. However, fruit loosening was largely prevented when 1-MCP was used in combination with coronatine or MeJa. Like ethephon, CMNP-induced fruit loosening was not affected by 1-MCP. The results demonstrate the ability to control ethephon-induced leaf abscission without affecting mature fruit loosening by targeting ethylene binding in citrus.
\end{abstract}

Citriculture remains a dominant economic force in Florida. Crop estimates indicate that the state will produce 246 million $40.8-\mathrm{kg}$ (90-lb) boxes of oranges in the 2003-04 season (Florida Agricultural Statistics Service, 2003). On a 40-kg-box basis, the $2000-01$ production cost of oranges destined for processing averaged $\$ 1.87$, while the cost of harvesting operations, on the other hand, rose to $\$ 2.10$ (Muraro et al., 2003). In contrast, the cost of production and harvesting in Brazil were $\$ 1.37$ and $\$ 0.53$, respectively. To remain competitive in a global market, Florida's citrus industry must become more efficient; in such a context, the mechanization of orange harvesting has become a priority.

Mechanical harvesting technologies such as trunk and canopy shakers are operational in Florida today, and fruit removal averages between $70 \%$ and $90 \%$ depending on factors such as grove conditions and tree architecture (Brown 2002). The development of abscission agents for use in combination with mechanical harvesting is expected to increase fruit removal percentages and speed of harvest while decreasing overall harvesting cost. An effective abscission agent can consistently loosen mature fruit without causing phytotoxicity to leaves and young developing fruit (Burns 2002). Ethephon (2-chloro-2-ethyl-phosphonic acid), methyl jasmonate (MeJa), 5-chloro-3-methyl-4-nitro- $1 H$-pyrazole (CMNP) and coronatine have been tested in Florida as abscission

Received for publication 19 Nov. 2003. Accepted for publication 12 Feb. 2004. This research was supported by the Florida Agricultural Experiment Station, a grant to JKB from the Florida Dept. of Citrus (03-31), and approved for publication as journal series R-09907. The authors gratefully acknowledge the expert technical assistance of Ana Redondo and Zhencai Wu, and the generous gift of SmartFresh $^{\circledast}$ from Harlow Warner of Rohm \& Haas, Inc.

'Corresponding author; e-mail jkbu@crec.ifas.ufl.edu. agents (Burns, 2002; Burns et al., 2003; Hartmond et al., 2000). These agents successfully loosen mature fruit, but only CMNP is specific for mature fruit within a wide concentration range. Ethephon chemically degrades to ethylene directly after uptake into alkaline plant tissue (Bukovac et al., 1969; Warner and Leopold, 1969), and CMNP, MeJa and coronatine induce ethylene evolution in responding tissues (Burns et al., 2003; Hartmond et al., 2000). It is thought that ethylene produced as a result of application of these agents promotes abscission.

Currently, no abscission agents are registered for use in citrus. It would be advantageous to adapt ethephon for use as an abscission agent because it is already registered for use on several food crops and is relatively inexpensive to apply. Unfortunately, under Florida's environmental conditions, ethephon causes unacceptably high leaf abscission when applied at concentrations effective to loosen mature citrus fruit (Burns, 2002). The action of ethephon is greatly affected by temperature, and high temperatures throughout the harvest season can increase efficacy of the material and consequently decrease the consistency of the response (Bukovac et al., 1969).

In recent years, the ethylene binding inhibitor 1-methylcyclopropene (1-MCP) has been used to delay or prevent senescence symptoms including abscission in floricultural commodities (Blankenship and Dole, 2003) and ethylene-related disorders associated with postharvest ripening, senescence, handling and decay of climacteric fruit such as apples (Saftner et al., 2003), peaches (Kluge and Jacomino, 2002), avocado and tomatoes (Jeong et al., 2002; Nakatsuka et al., 1997) and papaya (Jacomino et al., 2002). Although 1-MCP can inhibit or delay degreening in citrus, its application enhanced postharvest chilling injury and decay 
(Porat et al., 1999). Abscission in citrus leaf and fruit explants stored for various lengths of time can be prevented by the use of 1-MCP (Porat et al., 2001; Zhong et al., 2001), but work on effect of 1-MCP on whole citrus plants has not been extensively reported. In our previous work, we found that ethylene binding or perception inhibitors, such as 1-MCP and silver thiosulfate, reduced ethephon-induced leaf drop and gummosis in Citrus madurensis but only partially inhibited the ability of ethephon to loosen mature fruit (Pozo and Burns, 2000). The objective of this work was to determine if 1-MCP could be used in the field in combination with ethephon and other abscission agents to reduce defoliation while maintaining mature fruit loosening associated with the abscission agent.

\section{Materials and Methods}

Plant material. Citrus sinensis L. Osbeck cv. 'Valencia', grafted on rough lemon rootstock, and Citrus sinensis L. Osbeck 'Hamlin', grafted on 'Carrizo' citrange rootstock, were located at the Citrus Research and Education Center, Lake Alfred, Fla. Trees were between 15 and 18 years of age. Experiments were conducted in two harvest seasons.

Abscission agents And apPlication Procedures. 1-Methylcyclopropene (1-MCP) was obtained from Rohm and Haas, Inc., in either $0.14 \%$ or $3.3 \%$ active ingredient formulations (SmartFresh). Abscission agents used in this work were 1) ethephon [(2-chloroethyl) phosphonic acid (Ethrel, 21.7\% ethephon w/v, Aventis Crop Science, N.J.)], 2) coronatine, a natural product obtained by fermentation with Pseudomonas syringae (Burns et al., 2003), 3) methyl-jasmonate (MeJa) (Bedoukian Research Inc., Conn.), and 4) 5-chloro-3-methyl-4-nitro-1H-pyrazole (CMNP, 17.2\% active ingredient, as previously formulated by Abbott Laboratories, Ill.). All abscission agents were dissolved or dispersed in distilled water and contained the organosilicate adjuvant Kinetic (Setre Chemical Co., Tenn.) at $0.15 \%$ (v/v). Treatments were applied to canopy sections $\left(\approx 1 \mathrm{~m}^{3}\right)$ using a pressurized, 1-L capacity hand sprayer. For whole tree canopy treatments, a 12-L capacity pressurized back-pack sprayer was used. Spray solutions were applied until runoff. Rainfall did not occur for $3 \mathrm{~d}$ after application in all trials reported.

EXPERIMENT 1: LEAF ABSCISSION AND FRUIT LOOSENING WITH ETHEPHON. Spray solutions containing ethephon at 0, 200, 250, $300,350,400$, or $450 \mathrm{mg} \cdot \mathrm{L}^{-1}$ were applied to canopy sections bearing 80 to 300 leaves and no fewer than 10 mature fruit each. The experiment containing treatments described above were repeated twice in November to December ('Hamlin', $18^{\circ} \mathrm{C}$ avg. trial temps.) and twice in February to March ('Valencia', $23^{\circ} \mathrm{C}$ average trial temps.). The same row of 15 uniform trees was used for duplicated experiments with each cultivar. Four different randomly distributed sections were used per treatment at each time. In all cases, fruit detachment force (FDF) was measured 5 $\mathrm{d}$ after application with a digital force gauge (Force Five, Wagner Instruments, Greenwich, Conn.). Mature fruit with stems attached were clipped $\approx 2.5 \mathrm{~cm}$ above the fruit abscission zone, inserted into the gauge, and the stem pulled parallel to the fruit axis until it separated from the fruit. Results are expressed in kilograms. Cumulative percent leaf abscission was measured by counting leaves before and after periods up to $15 \mathrm{~d}$ postapplication. Results are expressed as a percentage of the starting leaf number.

EXPERIMENT 2: Timing OF 1-MCP APPLICATION. Spray solutions containing 1-MCP at $0,1,2.5$, and $5 \mathrm{~mm}$ were applied either 24 $\mathrm{h}$ before, in combination with, or $24 \mathrm{~h}$ after foliar sprays of 400 $\mathrm{mg} \cdot \mathrm{L}^{-1}$ ethephon. 1-MCPas SmartFresh was dissolved directly into the spray tank containing either water or ethephon and water, and applied within $5 \mathrm{~min}$. Additional treatments included $400 \mathrm{mg} \cdot \mathrm{L}^{-1}$ ethephon, $200 \mathrm{mg} \cdot \mathrm{L}^{-1} \mathrm{CMNP}$ and water as controls. Three randomly distributed canopy sections of 'Hamlin' orange, in a row of 15 trees, were used for each treatment. Each section contained 80 to 300 leaves and no fewer than five mature fruit. The experiment was repeated three times in November and December $\left(17.8^{\circ} \mathrm{C}\right.$ average trial temps.) using different canopy sections within the 15-tree row. FDF and cumulative percent leaf abscission were measured as described above, except leaf abscission was evaluated up to $30 \mathrm{~d}$ postapplication.

EXPERIMENT 3: 1-MCP/ETHEPHON COMBINATION APPLICATION ON WHOLE CANOPIES OF 'HAMLIN' ORANGE. The optimal timing and concentration of 1-MCP/ethephon applications was determined to be $5 \mathrm{~mm}$ 1-MCP applied in combination with ethephon to citrus canopies. Therefore, solutions containing $5 \mathrm{~mm} 1-\mathrm{MCP}$ and 400 $\mathrm{mg} \cdot \mathrm{L}^{-1}$ ethephon were prepared as described above and applied until runoff to entire canopies of 'Hamlin' orange trees in January and February $\left(14.6^{\circ} \mathrm{C}\right.$ average trial temps.). Additional treatments consisted of $400 \mathrm{mg} \cdot \mathrm{L}^{-1}$ ethephon, $200 \mathrm{mg} \cdot \mathrm{L}^{-1} \mathrm{CMNP}$, and water. In all treatments, three replicate trees were used. FDF was taken on 10 randomly selected fruit/tree and was monitored as described above. Cumulative percent leaf abscission was evaluated on four tagged branches/tree on no fewer than 150 leaves/branch. Leaf abscission was monitored as described above for periods up to $30 \mathrm{~d}$ after application. Juice analysis was determined on fruit used for FDF analysis. Acid (percent, as citric acid), Brix, and acid/Brix ratio of mature fruit at harvest were determined using standard procedures.

EXPERIMENT 4: Fruit LOOSENING AND LEAF ABSCISSION WITH 1-MCP IN COMBINATION WITH CORONATINE, MEJA, CMNP, AND ETHEPHON. Spray solutions containing $200 \mathrm{mg} \cdot \mathrm{L}^{-1}$ coronatine, $15 \mathrm{~mm}$ MeJa, $200 \mathrm{mg} \cdot \mathrm{L}^{-1} \mathrm{CMNP}$, and $400 \mathrm{mg} \cdot \mathrm{L}^{-1}$ ethephon were applied alone or in combination with $5 \mathrm{~mm} 1-\mathrm{MCP}$ to canopy sections of 'Valencia' orange. Three canopy sections per treatment were used in a 15-tree row, each containing 50 to 200 leaves and no fewer than 10 mature fruit. FDF was monitored as described above. Cumulative percent leaf abscission was evaluated as described above for periods up to $30 \mathrm{~d}$ after application. The experiment was repeated three times in March and April $\left(19.4^{\circ} \mathrm{C}\right.$ average trial temps.).

STATISTICS. Data were computed and, if necessary, transformed to stabilize variance using arcsin transformation in MS-Excel functions (Microsoft, Redmond, Wash.). Data of Expt. 1 were analyzed as a one-way factorial, with ethephon as variable. Data of Expt. 2 were analyzed as a three-way factorial, with ethephon concentration, 1-MCP concentration, and spray timing as variables. Data of Expt. 3 were analyzed as a one-way factorial, with treatment as variable. Data of Expt. 4 were analyzed as a two-way factorial, with abscission agent and 1-MCP application as variables. Analysis of variance, regression analysis and Duncan's multiple range tests were performed on data of experiments 1, 2, 3, and 4 using the SAS statistical package (SAS Inst. Inc., Cary, N.C.).

\section{Results}

EXPERIMENT 1: HIGH LEAF ABSCISSION IS INDUCED BY ETHEPHON. After $15 \mathrm{~d}$, leaf abscission in control trees was $<10 \%$ in both 'Hamlin' and 'Valencia' (data not shown). Leaf abscission was increased by ethephon in a concentration-dependent manner in both cultivars (Fig. 1). In control trees, FDF was $\approx 10 \mathrm{~kg}$ (data not 
shown). A concentration of $400 \mathrm{mg} \cdot \mathrm{L}^{-1}$ ethephon was required to reduce the FDF below 50\%; however, at this concentration, leaf abscission was $>70 \%$ in both varieties.

EXPERIMENTS 2 AND 3: COMBINED APPLICATIONS OF 1-MCP AND ETHEPHON REDUCE DEFOLIATION BUT HAVE NO EFFECT ON ETHEPHONINDUCED REDUCTION IN FDF. Cumulative leaf abscission was over $90 \%$ with $400 \mathrm{mg} \cdot \mathrm{L}^{-1} 30 \mathrm{~d}$ after application (Fig. 2). Defoliation was greatly reduced when 1-MCP was combined with ethephon and applied to citrus canopy sections (Fig. 2, Table 1). Applying 1-MCP $24 \mathrm{~h}$ before or after ethephon application was not as effective, although $5 \mathrm{~mm} 1$-MCP applied $24 \mathrm{~h}$ before ethephon significantly reduced defoliation (Table 1). Ethephon combined with either 1 or $2.5 \mathrm{~mm} 1-\mathrm{MCP}$ controlled excessive leaf abscission in this trial; however, additional trials with 'Valencia' orange later in the season confirmed that $5 \mathrm{~mm} 1-\mathrm{MCP}$ was the most effective (data not shown). Consistency of response to 1-MCP was less perhaps because average temperatures were at least $10^{\circ} \mathrm{C}$ higher later in the season. Despite the positive effect of 1-MCP on leaf abscission, ethephon-induced reduction in FDF was not affected by 1-MCP applied at any concentration or timing (Fig. 3 , Table 2). Whole tree canopy applications of $5 \mathrm{~mm} 1$-MCP in combination with $400 \mathrm{mg} \cdot \mathrm{L}^{-1}$ ethephon were also effective in reducing defoliation, but had minimal effect on ethephon-induced reduction in FDF (Table 3). Juice quality of mature fruit at harvest was unaffected by any abscission agent and/or 1-MCP.

EXPERIMENT 4: EFFICACY OF SEVERAL ABSCISSION AGENTS IS DIFFERENTIALLY AFFECTED BY 1-MCP. Coronatine, MeJa, ethephon, and CMNP were applied to canopy sections of 'Valencia' orange
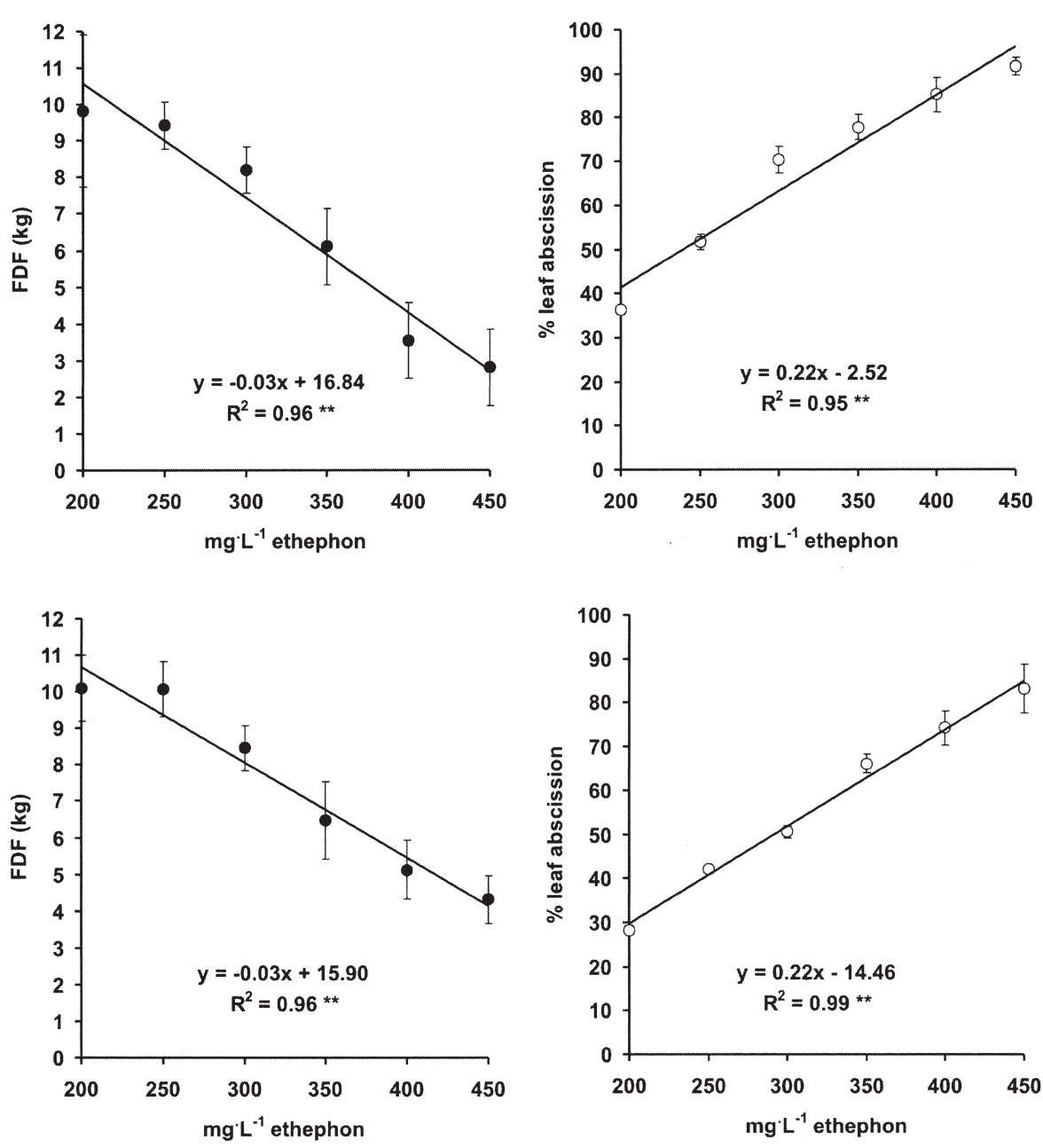

alone or in combination with 1-MCP to compare the abscission response of leaves and mature fruit. Cumulative percent leaf abscission induced by coronatine and MeJa alone was $\approx 20 \%$ (Fig. 4A). Combining the application of 1-MCP with these two abscission agents did not significantly affect leaf abscission, although the amount was numerically less. Leaf abscission induced by CMNP either alone or with 1-MCP was no different than the control. In contrast, 1-MCP significantly reduced defoliation induced by ethephon. Coronatine, MeJa, CMNP, and ethephon applications alone significantly reduced FDF (Fig. 4B). The reduction in FDF induced by CMNP or ethephon was not affected by 1-MCP treatment. However, little reduction in FDF occurred in the coronatine and MeJa treatments when 1-MCP was included in the spray application.

\section{Discussion}

The effect of the ethylene binding inhibitor 1-MCP on leaf and mature fruit abscission induced by ethephon and other agents has been investigated in citrus. In previous work under greenhouse conditions, we demonstrated that exposure of calamondin (Citrus madurensis) trees to 1-MCP applied as a gas $16 \mathrm{~h}$ before ethephon application or silver thiosulfate at the time of ethephon application greatly reduced gummosis and the defoliating effects of ethephon sprays, while only partially inhibiting ethephon-induced reduction of FDF (Pozo and Burns, 2000). This work has now been extended to the field with the commercial sweet orange cultivars 'Hamlin' and 'Valencia' using 1-MCP formulated as SmartFresh. Dissolving SmartFresh powder into the spray tank containing the abscission agent immediately before application and applying to citrus canopies reduced leaf abscission with little effect on ethephon-induced reduction in FDF. This is the first report demonstrating the use of SmartFresh powder for the purpose of specifically controlling leaf abscission in whole trees in the field. The selective effect of 1-MCP was optimal and consistent when 1-MCP was combined with the ethephon solution and immediately applied. It is unclear why 1-MCP application $24 \mathrm{~h}$ before ethephon treatment was not as effective, especially since it is thought that 1-MCPbinding is irreversible (Blankenship and Dole, 2003). A one-time, 'single-burst' application before ethephon sprays may not be adequate to reach and saturate all receptors in mature fruit. Application of 1-MCP $24 \mathrm{~h}$ after ethephon sprays was not sufficient to prevent abscission events once advanced by ethephon.

After SmartFresh is dissolved, application should not be delayed, as the gaseous active ingredient is quickly lost. Delays of $>5 \mathrm{~min}$ or more reduced the effectiveness of 1-MCP (data not shown). The volatility of the active ingredient is likely the primary reason why

Fig. 1. Effect of ethephon concentration applied as foliar sprays on FDF (in kilograms, $5 \mathrm{~d}$ after application) and leaf abscission (percent, $15 \mathrm{~d}$ after application). Upper graphs: 'Hamlin' orange, branch application on 25 Nov. 2002 (n =4). Lower graphs: 'Valencia orange', branch application on 7 Feb. $2003(n=4)$. The SE mean is indicated as bars through mean symbols. ${ }^{*}$ Significant at $P \leq 0.01$. 

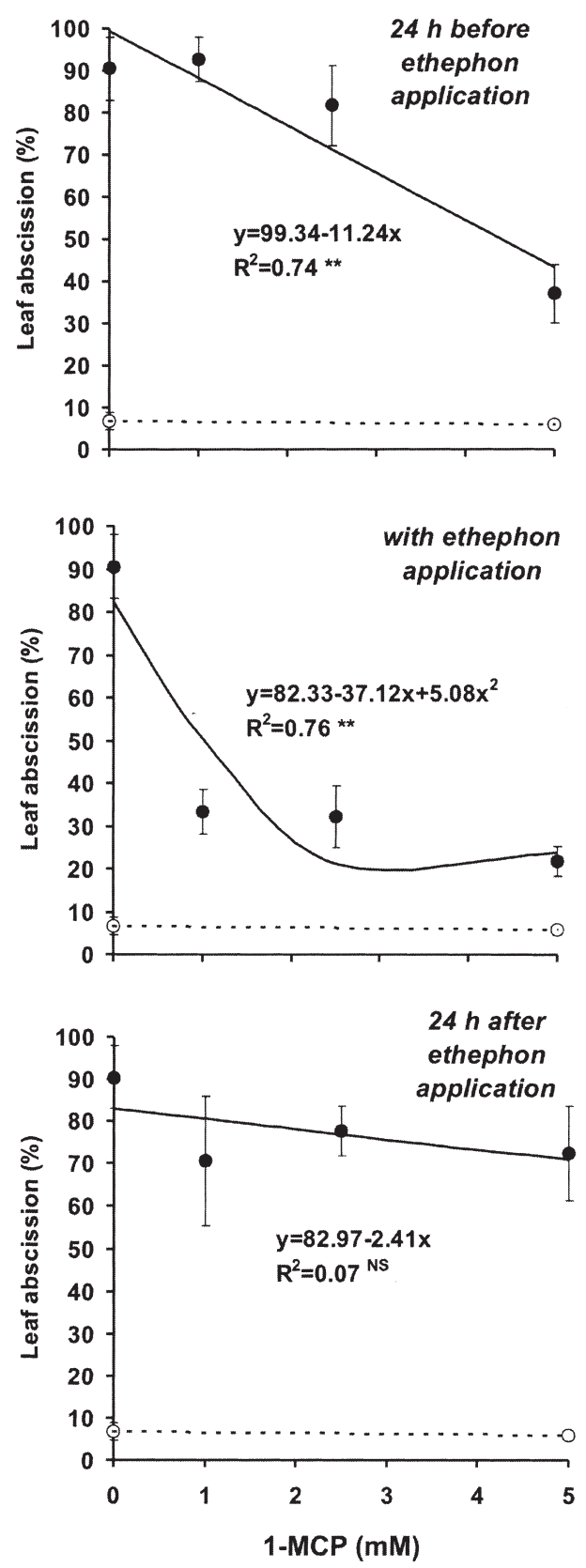

Fig. 2. Effect of 1-MCP concentration (mM) applied at different timings on leaf abscission induced by $400 \mathrm{mg} \cdot \mathrm{L}^{-1}$ ethephon sprays $(\mathbf{O})$. Leaf abscission caused by 0 and $5 \mathrm{~mm} 1-\mathrm{MCP}$ alone is shown $(\mathrm{O})$. Bars through mean symbols indicate SE mean $(n=3)$. Data are from a single representative experiment in 'Hamlin' orange on 27 Dec. 2002. Regression equations and $R^{2}$ values are shown for the

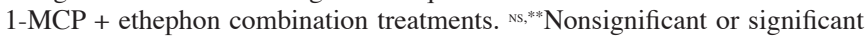
at $P \leq 0.01$, respectively.

Table 1. Effect of application time of 1-MCP on cumulative leaf abscission (percent, $30 \mathrm{~d}$ after application) of 'Hamlin' orange trees sprayed with $400 \mathrm{mg} \cdot \mathrm{L}^{-1}$ ethephon. ${ }^{\mathrm{z}}$

\begin{tabular}{lcccc}
\hline Application & \multicolumn{4}{c}{ 1-MCP concn (mM) } \\
\cline { 2 - 5 } timing & 0 & 1 & 2.5 & 5 \\
\hline 24 h before ethephon & 90.45 & $92.67 \mathrm{a}^{\mathrm{y}}$ & $81.71 \mathrm{a}$ & $36.99 \mathrm{~b}$ \\
Simultaneously & N/A & $33.37 \mathrm{~b}$ & $32.12 \mathrm{~b}$ & $21.72 \mathrm{~b}$ \\
24 h after ethephon & N/A & $70.73 \mathrm{a}$ & $77.72 \mathrm{a}$ & $72.52 \mathrm{a}$ \\
\hline
\end{tabular}

${ }^{z}$ Means of three replications of at least 80 leaves each.

y Mean separation within columns by Duncan's multiple range test, $P$ $\leq 0.05$.

${ }^{x} \mathrm{NA}=$ not applied.
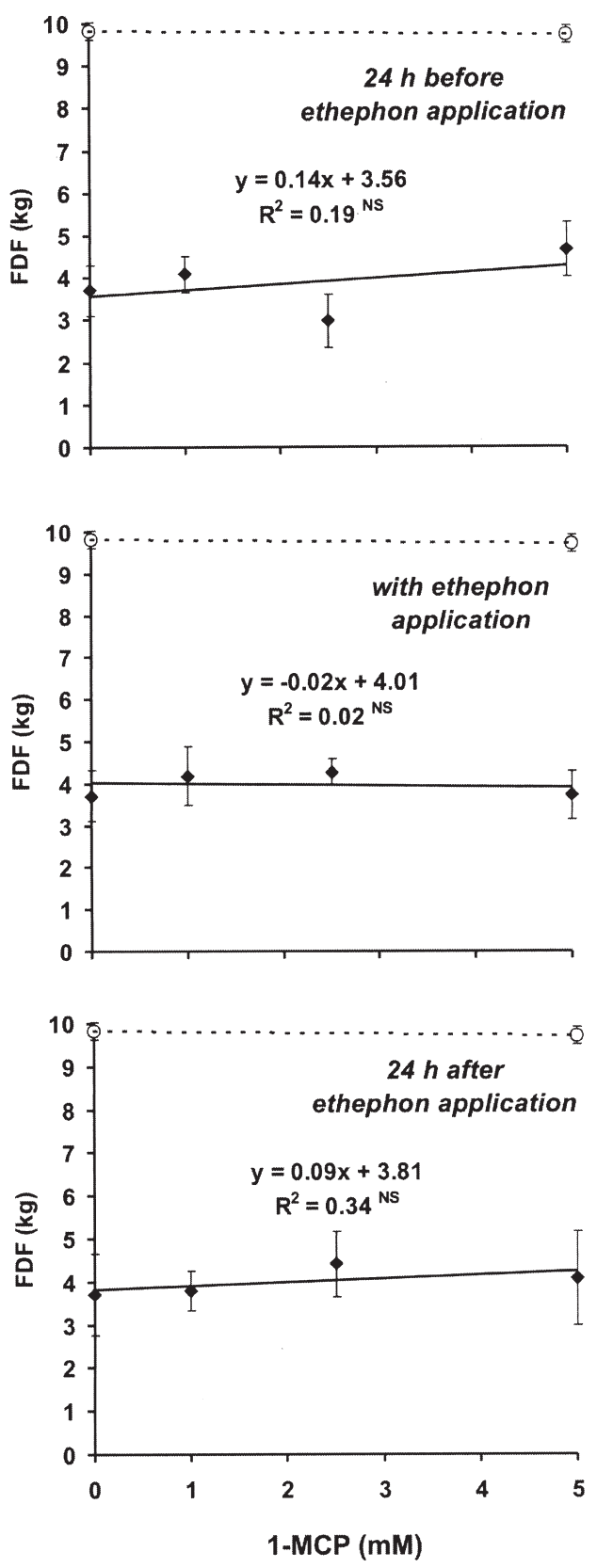

Fig. 3. Effect of 1-MCP concentration (mM) applied at different timings on FDF of 'Hamlin' orange trees sprayed with $400 \mathrm{mg} \cdot \mathrm{L}^{-1}$ ethephon (-). FDF affected by 0 and $5 \mathrm{~mm} 1-\mathrm{MCP}$ alone is shown $(\mathrm{O})$. Bars through mean symbols indicate SE mean $(n=3)$. Data are from a single representative experiment in 'Hamlin' orange on 27 Dec. 2002. Regression equations and $R^{2}$ values are shown for the

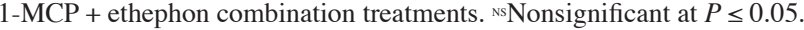

Table 2. Effect of application time of 1-MCP on FDF (in kilograms, $5 \mathrm{~d}$ after application) of 'Hamlin' orange trees sprayed with $400 \mathrm{mg} \cdot \mathrm{L}^{-1}$ ethephon. ${ }^{\mathrm{z}}$

\begin{tabular}{lcccc}
\hline Application & \multicolumn{4}{c}{ 1-MCP concn (mM) } \\
\cline { 2 - 5 } timing & 0 & 1 & 2.5 & 5 \\
\hline 24 h before ethephon & 3.708 & $4.090 \mathrm{a}^{\mathrm{y}}$ & $2.972 \mathrm{a}$ & $4.649 \mathrm{a}$ \\
Simultaneously & N/A & $4.179 \mathrm{a}$ & $4.270 \mathrm{a}$ & $3.719 \mathrm{a}$ \\
24 h after ethephon & N/A & $3.790 \mathrm{a}$ & $4.415 \mathrm{a}$ & $4.072 \mathrm{a}$ \\
\hline
\end{tabular}

${ }^{\mathrm{z}}$ Means of three replications of at least five fruit each.

yMean separation within columns by Duncans' multiple range test, $P$ $\leq 0.05$.

$\times \mathrm{NA}=$ not applied. 
Table 3. Effect of $5 \mathrm{~mm}$ 1-MCP alone, 5 mm 1-MCP combined with 400 $\mathrm{mg} \cdot \mathrm{L}^{-1}$ ethephon, ethephon alone, or $200 \mathrm{mg} \cdot \mathrm{L}^{-1} \mathrm{CMNP}$ on FDF, cumulative percent leaf abscission, percent acids, soluble solids, and ratio (soluble solids/percent acids) of juice at harvest. Entire canopies of 'Hamlin' orange trees were sprayed with treatment solutions as described in Materials and Methods. Means within columns with the same letters are not significantly different. (Duncan's multiple range test, $P \leq 0.05)$.

\begin{tabular}{|c|c|c|c|c|c|}
\hline Treatment & $\begin{array}{c}\text { FDF } \\
(\mathrm{kg}) \\
\end{array}$ & $\begin{array}{c}\text { Leaf } \\
\text { abscission } \\
(\%) \\
\text { dav } 30\end{array}$ & $\begin{array}{c}\text { Acids } \\
(\%) \\
\text { dav } 5\end{array}$ & $\begin{array}{c}\text { Soluble } \\
\text { solids } \\
\left({ }^{\circ} \text { Brix }\right) \\
\text { day } 5\end{array}$ & $\begin{array}{l}\text { Ratio } \\
\text { dav } 5\end{array}$ \\
\hline 1-MCP/ethephon & $5.6 \mathrm{~b}$ & $25.4 \mathrm{~b}$ & $0.68 \mathrm{a}$ & $12.80 \mathrm{a}$ & $18.94 \mathrm{a}$ \\
\hline Ethephon & $5.7 \mathrm{~b}$ & $64.2 \mathrm{a}$ & $0.69 \mathrm{a}$ & $12.76 \mathrm{a}$ & $18.82 \mathrm{a}$ \\
\hline 1-MCP & $9.4 \mathrm{a}$ & $6.4 \mathrm{c}$ & $0.68 \mathrm{a}$ & $12.83 \mathrm{a}$ & $18.82 \mathrm{a}$ \\
\hline CMNP & $4.6 \mathrm{c}$ & $7.9 \mathrm{c}$ & $0.68 \mathrm{a}$ & $12.85 \mathrm{a}$ & $18.96 \mathrm{a}$ \\
\hline Control & $9.3 \mathrm{a}$ & $6.1 \mathrm{c}$ & $0.68 \mathrm{a}$ & $12.84 \mathrm{a}$ & $19.00 \mathrm{a}$ \\
\hline
\end{tabular}

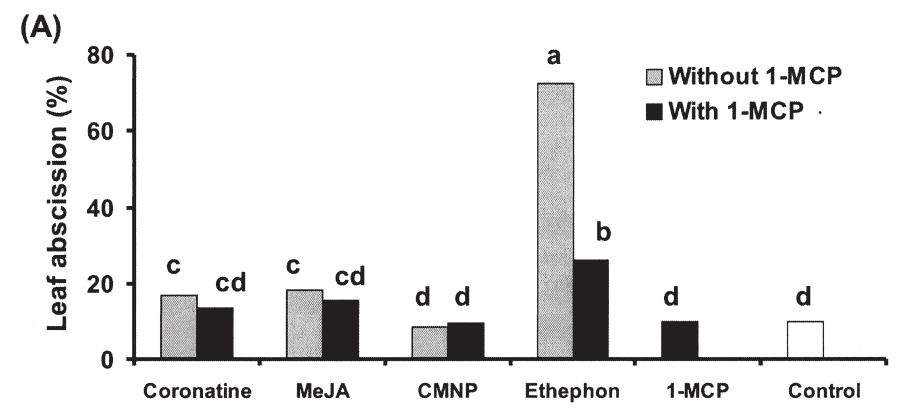

(B)

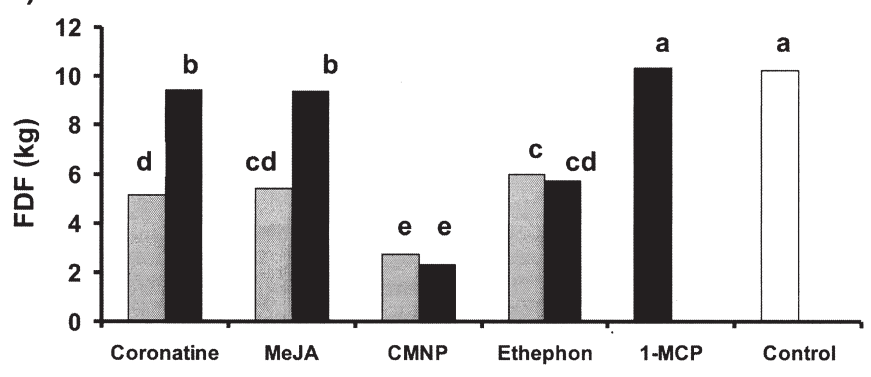

Fig. 4. Effect of 1-MCP at $5 \mathrm{~mm}$ on leaf abscission (A) and fruit detachment force (B) of 'Valencia' orange trees sprayed with coronatine, MeJa, CMNP, and ethephon, either alone or in combination with 1-MCP. Treatments were applied on 24 Apr. $2003(n=3)$. Treatments with the same letters are not significantly different from one another (Duncan multiple range test, $P \leq 0.05$ ).

optimal and predictable control of leaf abscission required $5 \mathrm{~mm}$ active ingredient. The solubility of the formulation prevented work with 1-MCP at higher concentrations. Clearly, application of 1-MCP by this method is inefficient and potentially costly. However, our work demonstrates that selectivity of ethephon can be improved by targeting the differential response of citrus leaves and mature fruit to compounds that block ethylene binding.

The response of citrus trees to combination applications of 1-MCP with ethephon or CMNP suggests that ethylene binding to its receptor(s) may not be necessary to advance mature fruit abscission. Mature citrus fruit are bulky organs subtended by a lignified peduncle, and it could be argued that 1-MCP is not reaching the target site(s) necessary to control fruit loosening. However, 1-MCP is readily diffusible through plant tissues, including bulky organs such as apples (Blankenship and Dole, 2003). Since the mature fruit abscission zone is located at the peduncle-mature fruit interface, 1-MCP likely is reaching the mature fruit abscission zone area. Further, 1-MCP greatly reduced fruit loosening when applied in combination with coronatine and $\mathrm{MeJa}$; compounds shown to induce abscission in citrus (Burns et al., 2003; Hartmond et al., 2000). This suggests that 1-MCP reached targets necessary to alter fruit loosening when these abscission agents were applied. Repeated attempts to block ethephon- or CMNP-induced fruit loosening in citrus with multiple applications of 1-MCP either in the field or with potted trees in growth chambers failed. Further, studies conducted on mechanically wounded 'Hamlin' and 'Valencia' orange fruit have shown that $1-\mathrm{MCP}$ was unable to stop the reduction of FDF resulting from peel wounding (Kostenyuk and Burns, unpublished results), suggesting that fruit abscission caused by wounding, or ethephon and CMNP application may not require ethylene binding to its receptor. Although it is generally assumed that abscission is initiated and regulated by ethylene, others have shown that ethylene perception per se may not be necessary, since abscission in Arabidopsis ethylene perception mutants still occurs, albeit delayed (Bleecker and Patterson, 1997; Johnson and Ecker, 1998). The Inflorescence Deficient in Abscission mutant of Arabidopsis fails to undergo abscission but is sensitive to ethylene (Butenko et al., 2003). In contrast to the response in mature fruit, ethephon-induced citrus leaf abscission was greatly reduced with 1-MCP. This effect is similar to that reported for other ethylene-related processes such as ripening (Golding et al., 1998; Harris et al., 2000; Hoeberichts et al., 2002) and physiological disorders such as apple scald (Fan and Mattheis, 1999).

There could be a number of reasons for the differential effect of 1-MCP on ethephon-induced leaf and mature fruit abscission. The effectiveness of 1-MCP could be influenced by tissue sensitivity to ethylene or the abscission agent, developmental age or the ability of tissues to regenerate active binding sites. Blankenship and Dole (2003) indicated that there are few data supporting the regeneration of active binding sites as a mechanism for gaining sensitivity to ethylene. However, it is well known that tissue sensitivity to ethylene is altered with increased age (Roberts et al., 2002). Furthermore, once ripening is initiated, 1-MCP becomes less effective at preventing and delaying ripening events in tomato (Hoeberichts et al., 2002), and it is possible that advanced senescence renders mature citrus fruit less responsive or unresponsive to 1-MCP. Events that prepare citrus fruit for abscission may occur at a developmental age before abscission agents are typically applied. In this case, ethylene itself or agents that result in ethylene generation may act as abscission accelerants. Accordingly, it has been suggested that ethylene accelerates rather than initiates pod dehiscence, cell separation processes in general (Roberts et al., 2002) and ripening (Theologis, 1992). Acomplex balance between endogenous hormones likely play a major role in the regulation of initiation and timing of abscission. The auxin/abscisic acid ratio was correlated with the ability of mature citrus fruit to respond to abscission agents (Yuan et al., 2001).

CMNP is an abscission compound that induces mature fruit but not leaf abscission over a wide concentration range (Burns, 2002). It is thought that CMNP promotes mature fruit abscission by enhancing ethylene production through chemical wounding of the peel (Wheaton et al., 1977; Wilson, 1973). Based on results presented here and elsewhere (Pozo and Burns, 2000), both ethephon- and CMNP-induced mature fruit abscission are likely to occur through a mechanism(s) that share common features. In contrast, 1-MCP applied as a single-burst largely prevented the reduction of FDF induced by the octadecanoid compounds $\mathrm{MeJa}$ and its biological analog coronatine, suggesting these 
compounds induce abscission through a common pathway, but different from ethephon and CMNP. MeJa is thought to initiate some abscission processes in an ethylene-independent manner by modifying polysaccharide metabolism in the abscission zone (Ueda et al., 1996) along with the mechanical weakening of cell wall (Miyamoto et al., 1997). Nevertheless, our results indicate that ethylene binding was required for effective mature fruit loosening induced by MeJa and coronatine, but not for CMNP or ethephon. These results raise the possibility of both ethylene-dependent and ethylene-independent mechanisms leading to mature fruit abscission in citrus. However, we cannot exclude the possibility that ethephon and CMNP, and not MeJa and coronatine, induce the synthesis of additional receptors that would be capable of binding ethylene after 1-MCP application and induce downstream abscission events.

In conclusion, we have shown that selectivity of ethephon used as an abscission agent for mature citrus fruit can be improved by targeting the differential response of leaves and mature fruit to the ethylene binding inhibitor 1-MCP. Therefore, the usefulness of ethephon as an abscission agent can be enhanced by limiting its adverse effect on leaf abscission through the use of 1-MCP. Specifically, combination applications of ethephon and 1-MCP prevented ethephon-induced leaf abscission without greatly affecting the reduction of FDF. Practical application of combination treatments of ethephon and 1-MCP awaits the development of a sprayable formulation or the successful development of a nongaseous 1-MCP analog that will ensure efficient delivery of the active ingredient to the site of action.

\section{Literature Cited}

Blankenship, S. and J.M.Dole. 2003. 1-Methylcyclopropene: A review. Postharvest Biol. Technol. 28:1-25.

Bleecker,A.B. and S.E. Patterson. 1997. Last exit: Senescence, abscission and meristem arrest in Arabidopsis. Plant Cell 9:1169-1179.

Brown, G. K. 2002. Mechanical harvesting systems for the Florida citrus juice industry. Amer. Soc. Agr. Eng. Paper 021108.

Bukovac, M.J., F. Zucconi, R.P. Larsen, and C.D. Kesner. 1969. Chemical promotion of fruit abscission in cherries and plums with special reference to 2-chloroethylphosphonic acid. J. Amer. Soc. Hort. Sci. 94:226-230.

Burns, J.K. 2002. Using molecular biology tools to identify abscission materials for citrus. HortScience 37:459-464.

Burns, J.K., L.V. Pozo, C.R. Arias, and B. Hockema. 2003. Coronatine and abscission in citrus. J. Amer. Soc. Hort. Sci. 128:309-315.

Butenko, M., S.E. Patterson, P.E. Grini, G.-E. Stenvik, S.S. Amundsen, A. Mandal, and R.B.Aalen. 2003. Inflorescence Deficient In Abscission controls floral organ abscission in Arabidopsis and identifies a family of putative ligands in plants. Plant Cell 15:2296-2307.

Fan, X. and J.P. Mattheis. 1999. Impact of 1-methylcyclopropene and methyl jasmonate on apple volatile production. J. Agr. Food Chem. 47:2847-2853.

Florida Agricultural Statistics Service, 2004. Citrus production forecast, 10 Feb. 2004. http://www.nass.usda.gov/fl/cpfp.htm.

Golding, J.B., D. Shearer, S.G. Wyllie, and W.B. McGlasson. 1998. Application of 1-MCP and propylene to identify ethylene-dependent ripening processes in mature banana fruit. Postharv. Bio. Technol. 14:87-98.

Hartmond, U., R. Yuan, J.K. Burns, A. Grant, and W.J. Kender, 2000. Citrus fruit abscission induced by methyl-jasmonate. J. Amer. Soc. Hort. Sci. 125:547-552.
Harris, D.R., J.A. Seberry, R.B.H. Wills, and L.J. Spohr. 2000. Effect of fruit maturity on efficiency of 1-methylcyclopropene to delay the ripening of bananas. Postharv. Biol. Technol. 20:303-308.

Hoeberichts, F.A., L. Van Der Plas, and E.J. Woltering. 2002. Ethylene perception is required for the expression of tomato ripening-related genes and associated physiological changes even at advanced stages of ripening. Postharv. Biol. Technol. 26:125-133.

Jacomino, A.P., R.A. Kluge, A. Brackmann, P.R. DeCamargo. 2002. Amadurecimiento e senescencia de mamao com 1-metilciclopropeno. Scientia Agricola 59:303-308.

Jeong, J., D.J. Huber, and S.A. Sargent. 2002. Influence of 1-methylcyclopropene (1-MCP) on ripening and cell wall matrix polysaccharides of avocado. Postharv. Biol. Technol. 25:241-256.

Johnson, P.R. and J.R. Ecker. 1998. The ethylene gas signal transduction pathway: A molecular perspective. Annu. Rev. Genet. 32:227-254

Kluge, R.A. and A.P. Jacomino. 2002. Shelf life of peaches treated with 1-methylcyclopropene. Scientia Agricola 59:69-72.

Miyamoto, K., M. Oka, and J. Ueda. 1997. Update on the possible mode of action of the jasmonates: Focus on the metabolism of cell wall polysaccharides in relation to growth and development. Physiol. Plant. 100:631-638.

Muraro, R.P., T.H. Spreen, and M. Pozzan. 2003. Comparative costs of growing citrus in Florida and Sao Paulo (Brazil) for the 2000-01 season. Fla. Coop. Ext. Serv. Inst. Food Agr. Sci. EDIS Publ. http: //edis.ifas.ufl.edu/FE364.

Nakatsuka, A., S. Shiomi, Y. Kubo, and A. Inaba. 1997. Expression and internal feedback regulation of ACC synthase and ACC oxidase genes in ripening tomato fruit. Plant Cell Physiol. 38:1103-1110.

Porat, R., B. Weiss, L. Cohen, A. Daus, R. Goren, and S. Droby. 1999. Effects of ethylene and 1-methylcyclopropene on the postharvest qualities of 'Shamouti' oranges. Postharv. Biol. Technol. 15:155-163.

Porat, R., X. Feng, M. Huberman, D. Galili, R. Goren, and E.E. Goldschmidt. 2001. Gibberellic acid slows postharvest degreening of 'Oroblanco' citrus fruits. HortScience 36:937-940.

Pozo, L. and J.K. Burns. 2000. Ethylene action inhibitors reduced Ethrelinduced leaf drop and gummosis in citrus. Proc. Intl. Soc. Citric. IX Congr. p. 578-579.

Roberts, J.A., K.A. Elliot, and Z.H. Gonzalez-Carranza. 2002. Abscission, dehiscence, and other cell separation processes. Annu. Rev. Plant Biol. 53:131-158.

Saftner, R.A., J.A. Abbott, W.S. Conway, and C.L. Barden. 2003. Effects of 1-methylcyclopropene and heat treatments on ripening and postharvest decay in 'Golden Delicious' apples. J. Amer. Soc. Hort. Sci. 128:120-127.

Theologis, A. 1992. One rotten apple spoils the whole bushel: the role of ethylene in fruit ripening. Cell 70:181-184.

Ueda, J., K. Miyamoto, and M. Hashimoto. 1996. Jasmonates promote abscission in bean petiole explants: Its relationship to the metabolism of cell wall polysaccharides and cellulase activity. J. Plant Growth Regulat. 15:189-195.

Warner, H.L. and A.C. Leopold. 1969. Ethylene evolution from 2-chloroethylphosphonic acid. Plant Physiol. 44:156-158.

Wheaton, T.A., W.C. Wilson, and R.E. Holm. 1977. Abscission response and color changes in 'Valencia' oranges. J. Amer. Soc. Hort. Sci. 102: 580-583.

Wilson, W.C. 1973. Problems encountered using cycloheximide to produce abscission of oranges. HortScience 8:323-324.

Yuan, R., U. Hartmond, and W.J. Kender. 2001. Physiological factors affecting response of mature 'Valencia' oranges to CMN-pyrazole. II. Endogenous concentrations of indole-3-acetic acid, abscisic acid and ethylene. J. Amer. Soc. Hort. Sci. 126:420-426.

Zhong, G., Y. Huberman, M. Fend, X.Q. Sisler, D. Holland, and R. Goren. 2001. Effect of 1-methylcyclopropene on ethylene-induced abscission in citrus. Physiol. Plant. 113:134-141. 